Columbia Law School

Scholarship Archive

1999

\title{
The Limits of Discipline: Ownership and Hard Budget Constraints in the Transition Economies
}

\author{
Roman Frydman \\ roman.frydman@nyu.edu \\ Cheryl W. Gray \\ author55598@ssrn.com \\ Marek P. Hessel \\ hessel@fordham.edu \\ Andrzej Rapaczynski \\ Columbia Law School, ar5@columbia.edu
}

Follow this and additional works at: https://scholarship.law.columbia.edu/faculty_scholarship

Part of the Banking and Finance Law Commons, and the Law and Economics Commons

\section{Recommended Citation}

Roman Frydman, Cheryl W. Gray, Marek P. Hessel \& Andrzej Rapaczynski, The Limits of Discipline: Ownership and Hard Budget Constraints in the Transition Economies, ECONOMICS OF TRANSITION \& institutional Change, Vol. 8, P. 577, 2000; Columbia LaW School, THE CENTER FOR LAW \& ECONOMic Studies WORKING PAPER NO. 165 (1999).

Available at: https://scholarship.law.columbia.edu/faculty_scholarship/1203

This Working Paper is brought to you for free and open access by the Faculty Publications at Scholarship Archive. It has been accepted for inclusion in Faculty Scholarship by an authorized administrator of Scholarship Archive. For more information, please contact scholarshiparchive@law.columbia.edu. 


\author{
Columbia Law School \\ The Center for Law and Economic Studies \\ 435 West $116^{\text {th }} \mathrm{St}$. \\ New York, NY 10027-7201
}

Working Paper No. 165

The Limits of Discipline: Ownership and Hard
Budget Constraints in the Transition Economies

Roman Frydman

New York University

Cheryl W. Gray

World Bank

Marek P. Hessel

Fordham University

Andrzej Rapaczynski

Columbia University School Of Law

February, 1999

This paper can be downloaded without charge from the Social Science Research Network electronic library at: http://papers.ssrn.com/paper.taf?abstract id=209112

An index to the working papers in the Columbia Law School Working Paper Series is located at: http://www.law.columbia.edu/lawec/ 


\title{
THE LIMITS OF DISCIPLINE: OWNERSHIP AND HARD BUDGET CONSTRAINTS IN THE TRANSITION ECONOMIES ${ }^{1,2}$
}

\author{
Roman Frydman, Department of Economics, New York University \\ Cheryl Gray, The World Bank \\ Marek Hessel, Graduate School of Business, Fordham University \\ Andrzej Rapaczynski, Columbia University School of Law
}

February 1999

\begin{abstract}
This paper, based on a large sample of mid-sized manufacturing firms in the Czech Republic, Hungary and Poland, argues that the imposition of financial discipline is not sufficient to remedy ownership and governance-related deficiencies of corporate performance. The study offers three main conclusions. First, we find that state enterprises represent a higher credit risk both because of their inferior economic performance and because of their lesser willingness or propensity to meet their payment obligations. Second, the brunt of the state firms' lower creditworthiness is borne by their state creditors, as state enterprises deflect the higher risk away from private creditors. Third, this transfer of risks from private to state creditors is possible because state creditors impose significantly "softer" financial discipline on state firms. Inasmuch as such softness may reflect unwillingness to accept a likely demise of a large number of state firms that are in principle capable of successful restructuring through ownership changes, we conclude that the imposition financial of financial discipline is not sufficient to remedy ownership and governancerelated deficiencies of corporate performance.

JEL Classification: G32, P17, P27, P31. Keywords: ownership; financial discipline; transition economies

${ }^{1}$ All correspondence should be directed to Andrzej Rapaczynski, Columbia University School of Law, 435 West $116^{\text {th }}$ Street, New York, NY 10027. Telephone: (212) 854-3421. Fax: (212) 854-7946. E-mail: ar5@columbia.edu.

${ }^{2}$ The authors would like to thank Joel Turkewitz for his contributions to the design and implementation of the survey instrument, and Mihaela Popescu for her extraordinary assistance in the analysis of the data. The authors also thank Sarbajit Sinha for computer support in the initial stages of research. Helpful conversations with, and comments from, Marvin Chirelstein, William Green, Glenn Hubbard, and Mark Roe are also gratefully acknowledged.

The authors are grateful to the CEU Foundation, the Open Society Institute and the World Bank for supporting research on this paper. CV Starr Center for Applied Economics at New York University has provided additional support for Roman Frydman's research. None of these institutions are responsible for the opinions expressed in this paper.
\end{abstract}




\section{Introduction}

Financial discipline is often viewed as the most important prerequisite of efficient corporate performance, and indeed of the health of the economy as a whole. "Soft budget constraints" have long been seen as a primary source of inefficiency of communist firms and as responsible for the ultimate failure of the socialist regimes (Gomulka, 1985; Kornai, 1993). More recently financial crises around the world have been attributed to lax financial practices on both governmental and firm levels. Not surprisingly, therefore, the various "rescue packages" have stressed the need for greater financial discipline and made it into the most important condition of economic assistance.

Without denying that financial discipline plays a very important role in corporate performance, this paper argues, using empirical evidence from the postcommunist transition economies, that there are clear limits, deriving from the governance and ownership structure of firms, to what financial discipline can accomplish. Although financial constraints restrict waste and force better cost management, the prospects of a firm's ultimate success (and the vibrancy of the economy as a whole) depends in large measure on the degree of inventiveness, creativity, and readiness to accept risk on the part of persons responsible for corporate decisions. These characteristics, often embraced in the general concept of entrepreneurship, have only an indirect relation to financial discipline and there are reasons to believe that financial discipline is not a sufficient condition for their promotion and development. Indeed, the main thrust of the arguments in this paper is that the very attempts to impose truly "hard" budget constraints through reforms of the financial sector and stringent macroeconomic measures, although in themselves desirable, may not be feasible without control changes on the level of the firms. In other words, the question is not so much one of whether a regime of hard budget constraints should be established, but whether it can be effectively established without an adequate governance and ownership reforms.

Our evidence comes from a study of small and medium-sized firms in three most advanced 
transition economies of Central Europe. In all three of these countries, trade and bank creditors are imposing harder constraints on loss-making firms (Schaffer, 1998). There is also considerable support for the proposition that a hardening of budget constraints forces not only private, but also state firms to economize on available financial resources (Pinto, Belka and Krajewski, 1993). Similarly, Balcerowicz, Gray, and Hashi (1997) document extensive employment changes among the largest state firms in Central Europe, which were presumably in large part prompted by the tightening of budget constraints. The streamlining of the cost side of the state enterprises' operations in response to external discipline is in fact quite effective: unless the state is active in company decisions, the restructuring of state enterprises in the transition environment of Central Europe tends to lower costs by margins similar to those achieved in privatized firms (Frydman et al., 1999; Frydman, Hessel, and Rapaczynski, 1998).

What ultimately matters in credit markets, however, is a firm's ability to pay, and even the strictest financial discipline will not allow firms to keep covering their obligations if they cannot generate sufficient revenues. We have shown elsewhere (Frydman et al., 1999) that the ability to generate revenue, especially during rapid economic change, is inherently tied to firm ownership, and that firms privatized to certain types of owners enjoy a significant performance advantage in this respect over their state counterparts. In this paper, we begin by showing that state firms also represent higher credit risk than their privatized counterparts.

We then proceed to show that state firms are not only less able to pay their creditors (by virtue of their lower ability to generate revenues); they are also less willing to do so, as compared to privatized firms with a similar ability to pay. As long as a firm generates enough revenues to pay some (or all) of its obligations, which ones (or whether) it will chose to repay depends on a number of factors, including the relative urgency of various obligations, the expectations of different creditors, the nature of the legal environment, the existence of alternative investment opportunities, etc. One of such factors, which is likely to play a role in state firms' willingness or propensity to repay, is the politicization of repayment decisions, especially if repayment forces layoffs and other politically difficult moves. As a result, state firms will be seen to represent significantly higher credit risks than their privatized or private counterparts, both because of their inferior revenue performance and the nature of their repayment decisions. 
In well-functioning credit markets, differences in creditworthiness of firms should be reflected in the allocation of credit. One would therefore expect that the higher credit riskiness of state firms would result in a stricter rationing of credit to those firms. Our data suggest this is indeed the case for trade credit. However, banks (and tax authorities) appear significantly "softer" in imposing financial discipline on state firms than on their privatized and private counterparts. Inasmuch as virtually all of those banks were state-owned at the time of the survey, we attribute this behavior in part to the likely politicization of credit decisions by state creditors.

But the softness of the budget constraints this introduces may not be just a matter of a "weakness of will" on the part of the relevant (state) actors. To be sure, the fact that state creditors continue to impose laxer discipline on state firms effectively amounts to a new subsidy. But this subsidy need not result from a merely undesirable kind of politicization of credit decisions that a better implementation of a tough credit policy would perhaps be able to avoid. Unless one is willing to accept a likely demise of a large number of state firms that cannot generate sufficient cash flows to survive, "rock hard" budget constraints might simply be unrealistic, and the subsidy provided by state creditors might be, to some extent, not irrational, especially if the firms in question are capable of successful revenue restructuring through ownership transformations [as may very well be the case in light of Frydman et al. (1999) and other studies there cited]. The conclusion we draw from this is not that the policy of hard budget constraints should be relaxed or abandoned, but that it cannot be made truly effective unless accompanied by speedy and effective privatization.

The paper proceeds as follows: Section II provides some univariate statistics concerning the sample on which the study is based. In Section III, we explain the assumptions about credit behavior that underlie our analysis. In Section IV, we evaluate the different risks that firms with different ownership types represent to their short-term creditors. In Section V, we examine the creditors' responses to those risks. Section VI examines the behavior of the firms in our sample with respect to the repayment of their long-term debts. We conclude in Section VII. 


\section{Ownership, performance, and credit arrears: an overview}

The analysis presented here is based on a survey of mid-sized firms in the Czech Republic, Hungary and Poland conducted in 1994-95. The firms were classified into four ownership types: private, privatized, noncorporatized state, and corporatized state firms. ${ }^{1}$ The subsample of firms used in this paper consists of 216 firms, 70 of which were in the Czech Republic, 90 in Hungary, and 56 in Poland. At the time of the survey, 31 percent of sample firms were held by the state (17 percent as corporatized entities), 43 percent were privatized, and 26 percent were private firms. (Additional sample description will be found in Appendix A.]

The four graphs in Figure 1 below illustrate the revenue performance of sample firms over the 1990-93 period and summarize the distributions of overdue short-term credit obligations (short-term bank credit, taxes to central and local governments, and trade credit) among firms with different revenue performance and ownership types. The first graph illustrates the trauma of the initial stages of transition and its impact on the revenue performance of the firms in our sample. In every year between 1990 and 1993 a majority of these firms suffered revenue losses. Indeed, 94 percent of state-owned firms had lower revenues in 1993 than in 1990; the 1993 revenues of 55 percent of privatized firms were still below their year-of-privatization levels; and 44 percent of private firms lost revenues between 1990 (or the year of establishment, if later) and 1993.

Even though state firms accounted for over a third of all firms in the sample, however, they constituted less then a twentieth of all growing firms: only 6 percent managed to gain revenues over the 1990-93 period, as compared to 45 percent of privatized and 56 percent of the (nonprivatized) private firms. Controlling for other factors, privatization alone, in the early stages of the postcommunist transition, "added" nearly 10 percentage points to the revenue growth rate of a firm privatized to owners not employed by the firm (Frydman et al., 1999).

\footnotetext{
${ }^{1}$ A firm was classified as private if it was never a state-owned enterprise. A previously state-owned firm was considered privatized if the combined holdings of private parties gave them a blocking power over major company decisions. In the absence of such power, the firm was classified, depending on its legal form, as a noncorporatized or corporatized state enterprise.
} 
Figure 1

Ownership, performance and credit arrears
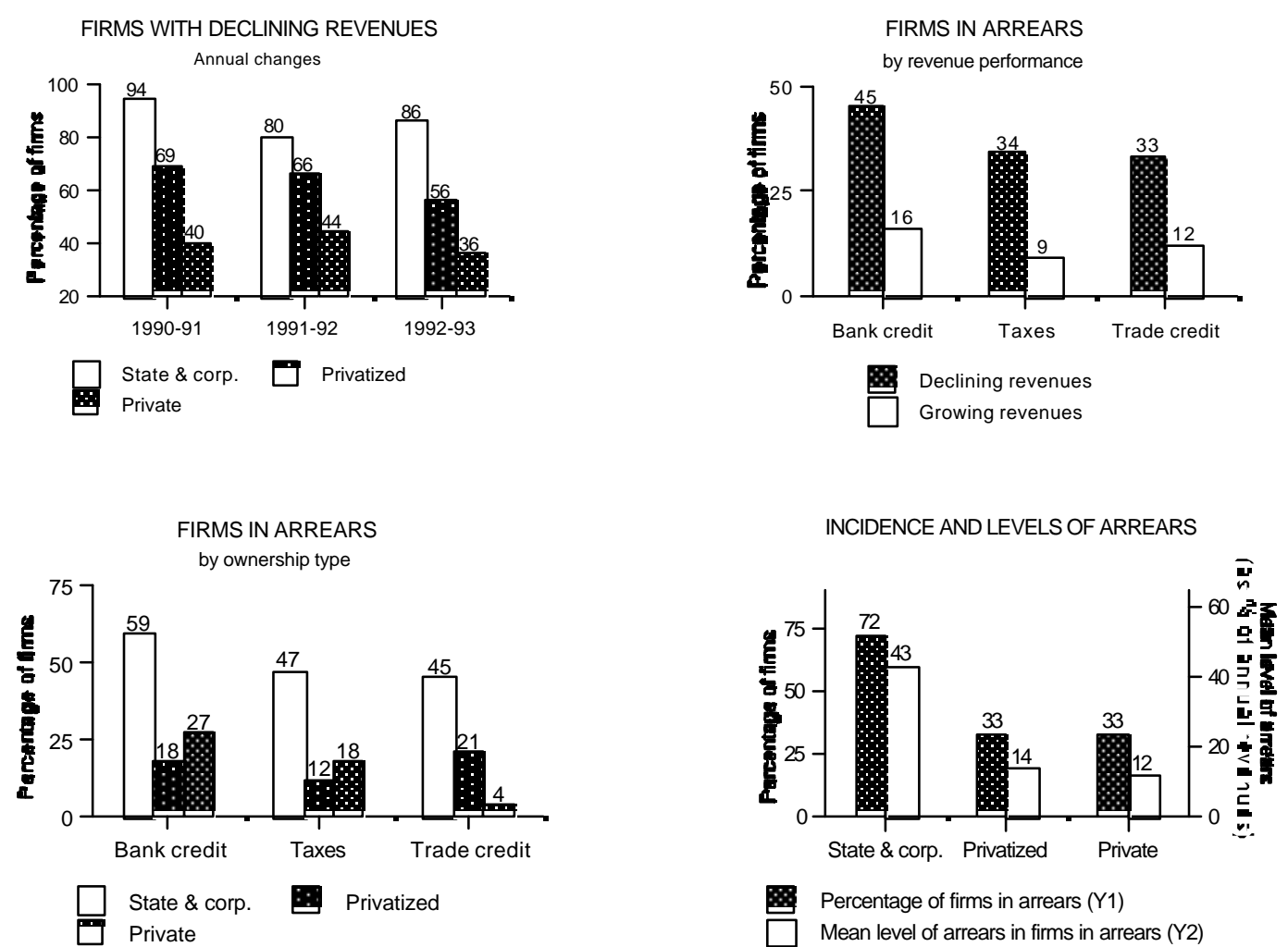

The decline of revenues in the early years of transition was bound to put many firms in financial difficulties. Overall, 45 percent of the firms in our sample were in arrears to one or more of their short-term creditors. ${ }^{2}$ Not surprisingly, the percentage was markedly higher among firms with declining revenues: 57 percent of such firms were in arrears to one or more of their creditors,

${ }^{2}$ In evaluating credit performance, we considered a firm to be in bank credit or tax arrears if any of its payments were past due. For trade credit, we defined overdue payments as those late by 60 or more days. This extension of the usual repayment period was necessary because delays in repaying trade credit within 30 days were quite common during the early stages of transition, particularly in the Czech Republic and Poland. In both of these countries, one out of every two firms failed to repay its suppliers within 30 days, the ratio dropping to one in three past 60 days (in Hungary, the ratio stood at one in four irrespective of the time period.) Moreover, the widespread incidence of "short" (under 60 days) delays overshadowed any systematic ownership differences, which surfaced only with the incidence of more persistent delays. 
as compared to 24 percent of those with growing sales (the difference significant at $\mathrm{p}<0.01$ ) and the second graph in Figure 1 shows that the performance-induced differences affected all three types of creditors.

The third graph in Figure 1 provides the distribution of firms in arrears by firm ownership.

State firms dwarf privatized and private firms in every credit category: proportionally at least twice as many state-owned firms as their privately-owned counterparts were late in meeting their obligations to all types of creditors. The last graph in Figure 1 summarizes the incidence and levels of overall short-term credit arrears (measured as a percentage of 1993 revenues) in firms with different types of owners: nearly 3 out of every 4 state and corporatized firms were in arrears to one or more of their short-term creditors, as compared to 1 out of 3 privatized and 1 out of 7 private firms (both differences significant at $\mathrm{p}<0.01$ ). Moreover, among the firms in arrears, the average level of combined arrears in state firms, amounting to 43 percent of annual revenues, was considerably higher than among the privatized (14 percent) and private (12 percent) firms.

\section{Measurement and evaluation of debtors' and creditors' behavior}

We make certain assumptions in what follows which it might help to state at the outset.

We assess the creditworthiness of a firm with certain characteristics (such as cost and revenue performance, ownership type, etc.) by estimating, on the basis of the data in our sample, the probability that a firm with these characteristics would have defaulted on any of its outstanding short-term credit obligations to any of its creditors during the 1990-1993 period. The higher the probability that a firm would have been late in meeting its obligations to one of its creditors, the lower the firm's overall creditworthiness (and the higher the credit risk it represents).

In addition to a firm's overall creditworthiness, we also evaluate the likelihoods of its being late with payments to particular types of creditors. In a well functioning market, and in the absence of any distinctive seniority structure of outstanding short-term obligations, those likelihoods should match the "overall" creditworthiness of the firm. Although we have no information on the terms of credit granted by different types of creditors, we see no prior reason for any short-term debts of any firms to be subordinated to other short-term debts in a systematic 
fashion. We therefore assume that, in principle, all short-term credit obligations are to be met pari passu and we interpret systematic differences in the likelihoods of arrears to different types of creditors as evidence that some firms give and/or receive preferential treatment to or from some types of creditors. (Of particular interest here is the behavior of state firms vis-a-vis state creditors.)

We break down the concept of a firm's creditworthiness into two components. The first is the firm's ability to pay. There is a number of factors that determine this ability: the firm's cash flows, the excess of its sales over costs, the degree of leverage, etc. Instead of all these, we use the firm's rate of revenue growth as a proxy for its ability to repay. The reason for this is, in part, that we have only limited data on the other factors, especially cash flows, and cannot recreate a complete evaluation that a lender may make before extending credit. (Information concerning a number of these factors, such as the cost of capital or profitability, is also somewhat artificial and notoriously unreliable in the early stages of the postcommunist transition and we doubt that the creditors are able to rely on them to any significant extent.)

But there is another, more important, reason why we believe that a firm's ability to service its debt obligations in the environment of the postcommunist transition is primarily a function of its ability to generate sufficient revenues. Where firms differ most in the transition environment, especially firms with different ownership types, is not in their ability to control costs (Frydman et al., 1999), but in their capacity to restructure their products and find new markets, so as to achieve a level of sales capable of assuring the firm's future viability. Once a firm's revenues are growing, costs can be kept in check, increasing the chances of being able to meet payment obligations. When the revenues are falling fast, on the other hand, even the most stringent cost cutting measures are unlikely to provide sufficient savings to enable the firm to compensate for the absolute shrinkage of its net gains from which the credit obligations must be serviced. Indeed, while we find in what follows a high level of dependence between the ability to generate revenues and creditworthiness, we found no statistically significant relation between a firm's cost performance and its ability to repay its obligations.

A firm's decision to repay any individual obligation, however, depends on more than its ability to come up with the cash; it involves a decision whether to allocate any available cash to 
this or another purpose. This decision reflects the component of the firm's creditworthiness that goes beyond the ability to pay, and involves the firm's willingness or propensity to repay. We gauge a firm's willingness to meet its credit obligations by the differential likelihood of its defaulting on its debt payments, as compared to other (types of) firms with a similar ability to pay. If state firms, for example, are more likely to default on their payments than the private ones, even after differences in ability to pay (as measured by revenue growth) are controlled for, we take this to be a reflection of these firms' lesser willingness or propensity to pay. ${ }^{3}$

While a firm's ability to pay is a function of firm-specific characteristics (in our model, essentially its ability to generate sufficient revenues to meet its payment obligations), its willingness or propensity to pay is a function of three different types of factors: (1) system-specific characteristics of the legal and economic environment, such as the extent of the credit market development, the nature and effectiveness of bankruptcy laws, etc.; (2) firm-specific characteristics, corresponding to how the firm values its relation with a given creditor, as compared to other claimants (including its labor force and any political constituencies that might support the priority of some claimants over others) and other available investment opportunities; (3) creditor-specific characteristics, related to how stringently the creditor will react to nonpayment or even a possibility of default. We assume that decisions to repay creditors are economic in nature, i.e., that they reflect the perceived balance between the costs of delaying payments to some or all of the creditors and the costs of foregone opportunities that timely payment involves. If, for example, state firms manifest lesser willingness or propensity to repay than privatized firms, this may be related in part to some internal pressures and preferences of state actors (such as those related to a politicization of repayment decisions) and in part to a relaxation

\footnotetext{
${ }^{3}$ This way of gauging the differences in the willingness or propensity to pay depends, of course, on the closeness of the "fit" between revenue growth and the ability to pay. To the extent that revenue growth may not be a perfect proxy, and thus may not capture certain aspects of a firm's ability to pay, those aspects may be "picked up" by other variables in our equations, especially those pertaining to ownership type. The most important potential candidate for such leakage would be the state firms' inferior cost performance. We have explained already that there is no statistically significant relation between cost performance and creditworthiness in our sample. We also know from Frydman et al. (1999) that state firms do not, as a matter fact, perform worse on costs than privatized companies. We do not believe, therefore, that the possibility of this kind of "leakage" is serious enough to vitiate our assumption that the significance of the coefficients of the ownership-type dummies in our equations reflects mostly differences in the willingness or propensity, and not the ability, to repay.
} 
of the budget constraints resulting from some "softness" with which state firms may be treated by all or certain types of creditors.

We attempt to gauge the separate effect of these factors, in particular the contribution that the creditors' behavior might make to the creditworthiness of a particular type of firms, in two ways. First, we assess the willingness or propensity of debtor firms to repay different types of creditors: a differential willingness of debtors to repay might be indicative of a differential willingness (or ability) of the creditors to collect. Second, we test the creditors' potential contribution to the likelihood of default by looking into the levels of arrears that certain types of firms may be permitted to run up. We assume that the closing of credit lines (rather than raising interest rates) is the primary method by which creditors are likely to ration credit in the early stages of the postcommunist transition. ${ }^{4}$ If a particular type of debtor, therefore, presents a known higher risk to a given creditor, the creditor will ration credit more strictly to this type of debtor (by requiring better revenue performance, for example), and will cut off credit once the arrears reach a certain level. (We assume that credit lines to defaulting borrowers can be shut off rather easily because short-term bank and trade credit are revolving in nature.) Thus, if the various factors affecting risk differentials among different types of firms are properly taken into account in the initial decisions to extend credit, the same factors should have no impact on the relative levels of arrears among the same types of firms. We take the evidence of the contrary phenomenon - i.e. that fact that the same factors account for both the incidence and the levels of overdue payments by some type of firms to certain types of creditors - as an indication that the creditors involved are either unaware of these factors' role in determining creditworthiness or,

${ }^{4}$ This is not uncommon even in well-functioning markets (Stiglitz and Weiss, 1981), and it is unlikely that interest rate variations played a significant role in credit allocation in the early years of the postcommunist transition. The inflation premia on loans were so high as to dwarf most firm-specific interest-rate adjustments. Also, with practically no credit history of firms under the conditions of a market economy, most creditors (especially banks) had limited ability to make fine differentiations in the degrees of risk represented by particular borrowers. Most credit allocation, therefore, is likely to be have been done through yes-or-no decisions on particular credit applications. (Although we do not have data on short-term interest rates in our survey, the data on long-term rates faced by the firms in our sample confirms this view, showing that the interests rates did not vary in relation to creditworthiness, with only some variations probably due to the presence of collateral. In fact, there was no statistically significant difference between the interest rates faced by state and privatized firms in our sample. New private firms faced an estimated 3\% surcharge, probably due to the fact that they were less likely to have valuable collateral.) 
more likely, ignore them and pursue "soft" credit policies with respect to firms with the characteristics in question. If state ownership, for example, turns out to be an explanatory factor with respect to both a firm's creditworthiness and the size of the arrears the firm may run up to state banks, we take this as evidence that state banks are "soft" in extending credit to state firms. This way of gauging the impact of creditors' behavior on the creditworthiness of their debtors will become important in disentangling the relationship between the policy of hard budget constraints and firm creditworthiness in the environment of the postcommunist transition.

\section{Ownership, revenue performance, and creditworthiness}

In this section, we examine the likelihood of a firm's default on its short-term obligations as a function of the firm's revenue performance, ownership type, and the country in which the firm is located. ${ }^{5}$ Since falling revenues are apt to affect the likelihood of default differently from the rising ones, we split the revenue growth into two corresponding variables. We estimate separately likelihoods of defaults on obligations to the following types of short-term creditors: (1) any creditors (2) bank creditors, (3) tax authorities, (4) any state creditors (banks or tax authorities), and (5) trade creditors. (Throughout, state firms in the Czech Republic have served as a reference group). The resulting estimates, together with a more detailed description of the variables used, appear in Table 1.

${ }^{5}$ We also tested for the impact of any sectoral differences among firms by including two-digit industry dummies as well as combinations of such dummies (capturing the difference between consumer and industrial goods sectors) among the variables in our model, and found that all such sectoral effects lacked significance and their inclusion left the estimates of other variables virtually intact. 


\section{Table 1: Probability of Default on Obligations TO DIFFERENT TYPES OF CREDITORS

\author{
(OVER 1991-93 PERIOD)
}

\begin{tabular}{|c|c|c|c|c|c|}
\hline \multirow[b]{2}{*}{ Variable } & \multicolumn{5}{|c|}{ Creditors to whom the debt is owed } \\
\hline & $\begin{array}{c}\text { (1) } \\
\text { Any } \\
\text { creditors }\end{array}$ & $\begin{array}{c}(2) \\
\text { Bank } \\
\text { creditors }\end{array}$ & $\begin{array}{c}\text { (3) } \\
\text { Tax } \\
\text { authorities }\end{array}$ & $\begin{array}{c}\text { (4) } \\
\text { State (banks } \\
\text { or tax } \\
\text { authorities) }\end{array}$ & $\begin{array}{c}(5) \\
\text { Trade } \\
\text { creditors }\end{array}$ \\
\hline Constant & $\begin{array}{l}-0.05 \\
(0.15)\end{array}$ & $\begin{array}{l}-0.13 \\
(0.12)\end{array}$ & $\begin{array}{l}-0.28^{*} \\
(0.09)\end{array}$ & $\begin{array}{l}-0.22 * * \\
(0.13)\end{array}$ & $\begin{array}{l}-0.13 \\
(0.10)\end{array}$ \\
\hline $\begin{array}{l}\text { Rate of growth of revenues for firms with } \\
\text { decreasing revenues }{ }^{1}\end{array}$ & $\begin{array}{l}-0.014^{*} \\
(0.004)\end{array}$ & $\begin{array}{l}-0.010 * \\
(0.003)\end{array}$ & $\begin{array}{l}-0.008^{*} \\
(0.002)\end{array}$ & $\begin{array}{l}-0.013^{*} \\
(0.003)\end{array}$ & $\begin{array}{l}-0.006^{*} \\
(0.002)\end{array}$ \\
\hline $\begin{array}{l}\text { Rate of growth of revenues for firms with } \\
\text { increasing revenues }{ }^{1}\end{array}$ & $\begin{array}{l}0.000 \\
(0.001)\end{array}$ & $\begin{array}{c}0.000 \\
(0.000)\end{array}$ & $\begin{array}{l}-0.000 \\
(0.000)\end{array}$ & $\begin{array}{c}0.000 \\
(0.000)\end{array}$ & $\begin{array}{l}-0.000 \\
(0.000)\end{array}$ \\
\hline Corporatized firm ${ }^{2}$ & $\begin{array}{l}-0.12 \\
(0.17)\end{array}$ & $\begin{array}{l}-0.37^{*} \\
(0.14)\end{array}$ & $\begin{array}{l}-0.32^{*} \\
(0.11)\end{array}$ & $\begin{array}{l}-0.26 * * \\
(0.14)\end{array}$ & $\begin{array}{l}0.02 \\
(0.11)\end{array}$ \\
\hline Privatized firm ${ }^{3}$ & $\begin{array}{l}-0.36^{*} \\
(0.15)\end{array}$ & $\begin{array}{l}-0.48^{*} \\
(0.13)\end{array}$ & $\begin{array}{l}-0.39^{*} \\
(0.10)\end{array}$ & $\begin{array}{l}-0.38^{*} \\
(0.13)\end{array}$ & $\begin{array}{l}-0.10 \\
(0.10)\end{array}$ \\
\hline Private (non-privatized) firm ${ }^{4}$ & $\begin{array}{l}-0.38 * \\
(0.16)\end{array}$ & $\begin{array}{l}-0.45^{*} \\
(0.13)\end{array}$ & $\begin{array}{l}-0.34 * \\
(0.10)\end{array}$ & $\begin{array}{l}-0.33 * \\
(0.14)\end{array}$ & $\begin{array}{l}-0.39 * \\
(0.11)\end{array}$ \\
\hline Hungary $^{5}$ & $\begin{array}{c}0.13 \\
(0.10)\end{array}$ & $\begin{array}{l}0.27 * \\
(0.09)\end{array}$ & $\begin{array}{l}0.36^{*} \\
(0.08)\end{array}$ & $\begin{array}{l}0.31 * \\
(0.09)\end{array}$ & $\begin{array}{c}-0.14^{* *} \\
(0.08)\end{array}$ \\
\hline \multirow[t]{2}{*}{ Poland $^{6}$} & $\begin{array}{c}0.14 \\
(0.12)\end{array}$ & $\begin{array}{l}0.35^{*} \\
(0.11)\end{array}$ & $\begin{array}{l}0.39 * \\
(0.09)\end{array}$ & $\begin{array}{l}0.29 * \\
(0.11)\end{array}$ & $\begin{array}{l}-0.01 \\
(0.09)\end{array}$ \\
\hline & $\begin{array}{c}\mathrm{n}=175 \\
\mathrm{P}^{2}=45.06^{*}\end{array}$ & $\begin{array}{c}\mathrm{n}=209 \\
\mathrm{P}^{2}=67.06^{*}\end{array}$ & $\begin{array}{c}\mathrm{n}=216 \\
\mathrm{P}^{2}=77.82 *\end{array}$ & $\begin{array}{c}\mathrm{n}=201 \\
\mathrm{P}^{2}=54.62^{*}\end{array}$ & $\begin{array}{c}\mathrm{n}=204 \\
\mathrm{P}^{2}=39.99 *\end{array}$ \\
\hline
\end{tabular}

*p \#0.05 **p \# 0.10; significant coefficients bold-faced. Maximum likelihood estimates of binomial probit models

${ }^{1}$ To smooth year-to-year variations in performance, the rates of revenue growth are annualized over the 1991-93 period for state firms and over the post-privatization period for privatized firms. (Thus, if $R_{t}$ denotes the value of a firm's revenue level in year $t$, the annualized rate of revenue growth, ARRG, is an imputed rate which satisfies $R_{1993}$ $/ R_{t}=(1+A R R G)^{(1993-t)}$.) To eliminate possible bias due to the use of different initial years in calculating annualized rates of growth for state and privatized firms, Table B.1 in Appendix B provides the regression statistics which obtain when the rates of growth for state firms are annualized between 1990-93. (Note that the choice of the initial year does not affect the significance or the order of magnitude of the estimates reported in this Table.)

Revenues are measured in constant local prices.

${ }^{2}$ A dummy variable equal to 1 if the firm is corporatized, zero otherwise.

${ }^{3}$ A dummy variable equal to 1 if the firm is privatized, zero otherwise.

${ }^{4}$ A dummy variable equal to 1 if the firm is a newly-founded by private parties, zero otherwise.

${ }^{5}$ A dummy variable equal to 1 if the firm is in Hungary, zero otherwise.

${ }^{6}$ A dummy variable equal to 1 if the firm is in Poland, zero otherwise. 
Obligations to all short-term creditors

Two features of the estimates, reported in column (1) of Table 1, of the likelihood of a firm's defaulting on any of its short-term obligations (regardless of the type of the creditor) deserve note. The first is the relationship between creditworthiness and the rate of revenue growth. The second is the impact of ownership on the willingness or propensity to repay.

We have conjectured that declining revenues are a proxy for a firm's decreasing ability to repay its obligations, and the coefficient of this variable $(-0.014)$ is highly significant, consistent with the conjecture. For firms with growing revenues, however, the likelihood of default is not related to the rate of revenue growth. This is not unexpected if growing revenues generally indicate sufficiently high ability to pay - as seems reasonable to assume in most instances. For then, once a firm's revenues are growing, its decision to repay (or not to repay) depends mostly on other factors, and the rate of growth itself is not predictive of the likelihood of arrears.

Although the rate of revenue growth is a "facially neutral" characteristic, we know that in fact state firms, in the early years of the transition, were losing revenues at a rate much faster than either those that had never been state-owned or had been privatized (see Figure 1 and the accompanying text). Indeed, all but three state and corporatized firms in our sample had declining revenues and the median rate of revenue growth of state firms during 1990-93 was $-20 \%$, while that of privatized firms was $-5 \%$ and that of private firms $10 \%$. Thus, to the extent that declines in revenue proxy for a lesser ability to pay and a higher likelihood of default, state firms are by this fact generally less creditworthy and will be hit much harder by any consistent policy of hard budget constraints.

But in addition to their lesser ability to pay, state firms also show lesser willingness or propensity to repay. Even when revenue performance is controlled for, the ownership contrasts for privatized and private firms $(-0.36$ and -0.38 , respectively) are both significant, indicating that those firms are significantly lees likely than their state counterparts to fall behind in their shortterm obligations. ${ }^{6}$ Thus, even as between state and privatized or private firms with the same

\footnotetext{
6 While the negative sign of the "corporatization" contrast suggests that corporatized firms may be lesser credit risks than noncorporatized state firms as well, the difference lacks statistical significance.
} 
ability to pay, state firms represent a higher risk to their short-term creditors. (Interestingly, privatized and private firms are statistically indistinguishable from each other insofar as their willingness or propensity to repay is concerned.) These differences in creditworthiness between state-owned and privately-owned firms are independent of the firms' domicile: once the revenue performance and ownership of a firm are accounted for, country effects are insignificant in predicting the likelihood of a firm's running late in meeting some of its payment obligations. (As we shall see, however, which of its obligations the firm is more likely to default on is not independent of the country in which the firm is located.)

The lower willingness or propensity of state firms to repay their short-term obligations may be, in part, a function of the way they are treated by their creditors. If the creditors impose "softer" budget constraints on state firms than on other firms, this lowers the cost of nonpayment and, if the opportunity costs of payment do not change, the state firms' propensity to repay is ipso facto reduced. We will inquire later whether there is reason to believe that at least some creditors are indeed softer on state firms. But there may also be other reasons why the state firms' willingness or propensity to repay is lower than that of their privately-owned counterparts, and these reasons may be specific to the state firms themselves. The most likely candidate would be a politicization of repayment decisions: paying one's debts may introduce cash constraints that may force layoffs or wage restrictions, or other cost-cutting measures that impinge on the firm's politically powerful constituencies. If state firms are more subject to political pressure by these constituencies, their opportunity cost of repayment is higher and raises the risk they represent to their creditors.

The estimates reported in Table 1 are the marginal effects evaluated at the mean values of explanatory variables, and comparisons of the creditworthiness of firms with different types of ownership might be facilitated by the probability curves generated by these estimates. Figure 2 shows these curves; to increase the clarity of graphic presentation, the probabilities were reestimated without country variables, which had lacked significance in the original equation. (Since few state firms have growing revenues, the graph compares only firms with declining revenues. The three marks on each probability curve identify the positions of the first, second, and third quartile firms in terms of the rate of revenue decline. The dotted horizontal line 
identifies the point of equal odds of meeting financial obligations on time.)

\section{Figure 2}

Likelihood of overdue payments

(firms with declining revenues)

\section{ALL SHORT-TERM CREDIT ARREARS}

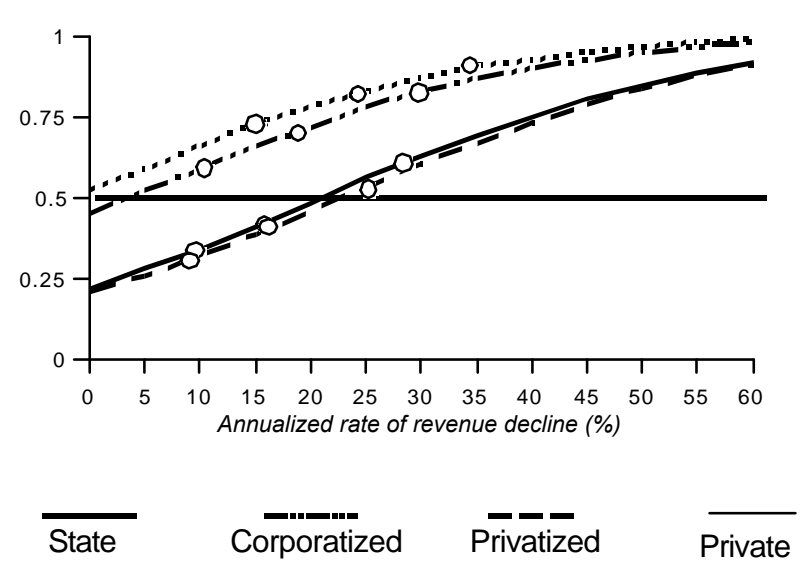

The slope of the probability curve for each type of firm reflects the extent to which credit risks change with changes in the rates of decline in revenue performance - all curves have positive slopes, as the accelerating revenue decline (and thus decreasing ability to pay) increases the risks of default to one or more short-term creditors. The height of each curve reflects the overall risks associated with a particular type of firm, and the relative positions of the curves reflect the risk differentials stemming from differences in the willingness or propensity to pay. The figure shows that practically all state and corporatized firms were more likely than not to run up arrears, and this "fit" between being state-owned and the more than $50 \%$ chance of default is made even closer by the fact that nearly all state firms in our sample had declining revenues (and thus are not omitted from the estimates in Figure 2).

On the other hand, the majority of privatized and private firms, even when their revenues were declining (and for many of them this was not the case) were more likely than not to meet all of their short-term payment obligations on time (their median rates of revenue decline -15.7 percent and 15.6 percent, respectively - were both below the 20 percent decline beyond which 
the probability of late payments for these firms exceeded 0.5). ${ }^{7}$ Another measure of the difference in the propensity to repay is the horizontal distance separating the probability curves in Figure 2. This distance suggests that a state firm would have to have about 20 percentage points higher revenue growth to be as creditworthy as a privatized firm with otherwise similar characteristics, a very severe handicap on state ownership. Should short-term creditors apply strictly nondiscriminatory lending criteria, the lower overall creditworthiness of state firms, reflecting both their lower ability and lower propensity to pay, might have resulted in a virtual credit cutoff to the state-owned sector. ${ }^{8}$

Bank, tax, and trade credit

Overall incidence of nonpayment to creditors is only a part of the story of the developing standards of creditworthiness in the transition economies. Debtors not only deal with the financial ups and downs during this difficult period by occasionally defaulting on their obligations; they also juggle their obligations to different types of creditors. Which creditors they tend to pay first and which they tend to skip when money is short tells quite a lot about the effectiveness of financial market reforms.

Columns $2-5$ of Table 1 show the estimates of how likely were the firms in our sample to default on their obligations to different types of short-term creditors: banks, tax authorities, and trade creditors. Since the banks lending to the firms in our sample were virtually all state-owned at the time, they and the tax authorities could, for most purposes, be considered together under the rubric of "state creditors," and we listed them as such in column 4 of Table 1 . We have also illustrated the comparisons of the creditworthiness of firms with different types of ownership vis à vis different types of short-term creditors by re-estimating the equations reported in the appropriate columns of Table 1 without country variables and presenting the relevant probability curves in Figure 3.

\footnotetext{
${ }^{7}$ Note also that the position of the third quartile privatized firm suggests about even odds (1:1) of default, while for a state firm with the identical rate of revenue decline the odds are higher than $4: 1$.

${ }^{8}$ As we explain later, however, some of the state firms' lower propensity to repay is itself attributable to the softness of their (state) creditors.
} 


\section{Figure 3}

Likelihood of default on obligations to banks, tax authorities, and trade creditors (for firms with declining revenues)
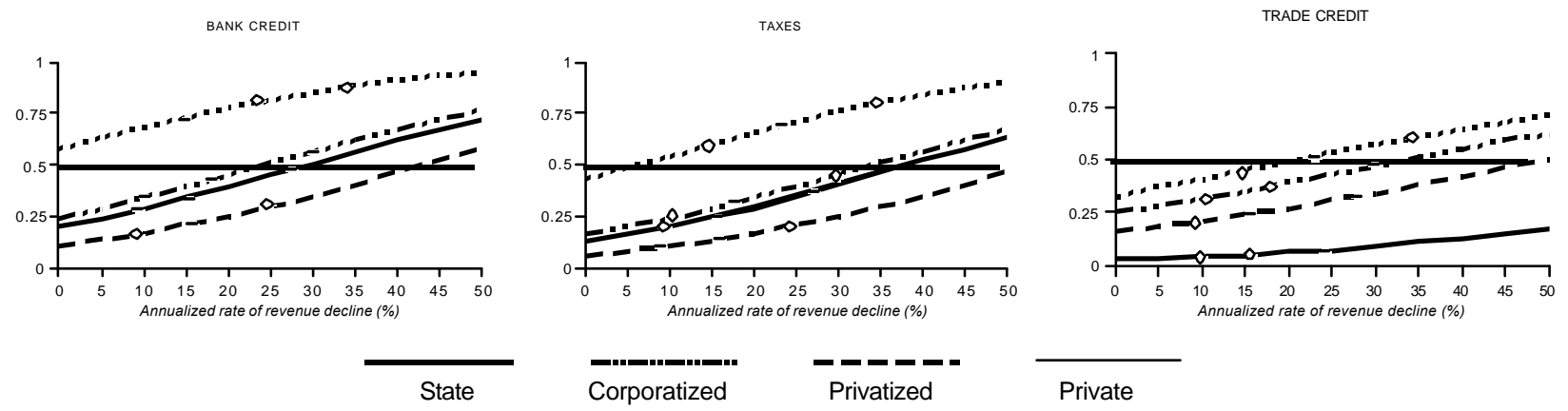

Private

The significance of the rate of a firm's declining revenues for the likelihood of default persists throughout all the equations reported in Table 1. On our assumption that revenue growth is a good proxy for the ability to pay, the remaining differences in the creditworthiness of firms with different ownership types are most likely due to differences in the willingness or propensity to repay. ${ }^{9}$ Perhaps the most interesting of these is the difference between the payment behavior of privatized firms and that of noncorporatized state-owned enterprises vis à vis state and trade creditors. The ownership contrasts for privatized firms in both bank and tax credit equations $(-0.48$ and -0.39 , respectively) are significant indicating that state and privatized enterprises differ significantly in their propensity to repay their short-term obligations to state creditors. The corresponding contrast in the trade credit equation $(-0.10)$, however, lacks significance, suggesting that after differences in revenue growth (the ability to pay) are controlled for, the remaining differences in the likelihood of default on obligations to trade creditors are no longer significant.

The fact that state firms appear as "resolved" as their privatized counterparts to pay their trade creditors on time may be due to several factors. One possible reason is that trade creditors may find it easier to enforce their payment schedules than banks or the tax authorities: if a firm is very dependent on its suppliers, it may be easy for a supplier to cut off deliveries, and the penalty

\footnotetext{
${ }^{9}$ But see the caveat in note 3 above.
} 
for the defaulting firm may be very high.

Another reason may be that state firms considered relations with their suppliers more important than their relations with the banks because the generally very high cost of bank credit in the inflationary period of the early transition meant that they could not afford to take on bank debt anyway, and were thus less concerned about preserving their credit rating with the banks. Privatized firms, by contrast, being in a generally better financial position, may not have faced as tough a choice between defaulting to one creditor or another, and were perhaps more likely to view bank credit as something they may afford. State firms may have also counted (with or without reason) on some reprieve from state banks and other state institutions that their privatized counterparts did not expect.

Finally, state creditors may have been in fact less tough than trade creditors in enforcing debt payments from state enterprises, but not from privatized firms; they may have been less capable of differentiating between good and bad credit risks, or they expected the government to make good in one way or another on the state firms' obligations, or perhaps they viewed state firms as operating under severe handicaps and in need of special treatment to avoid unnecessary factory closings, socially costly bankruptcies, etc.

Whatever the precise reason, the end result is the same: state enterprises were generally less able and less willing to repay their short-term debts than privatized firms, and thus more likely to default on some of their obligations. But the brunt of the state firms' lower creditworthiness was borne by their state creditors, as state enterprises shifted their limited resources toward payment of their trade creditors and deflected the increased risk away from their trade partners. This transfer or reassignment of risk from lending to state enterprises, which makes state firms appear more creditworthy to their suppliers, is illustrated in Figure 4, which contrasts, for state and privatized firms, the likelihood of a firm's default on bank obligations with the probability of its nonpayment of trade credit. While otherwise similar privatized firms are equally likely to default on their obligations to bank and trade creditors, state enterprises are significantly more likely to run up arrears to banks than to their suppliers. 


\section{Figure 4}

Likelihood of default on payments to banks and trade creditors by state and privatized firms (firms with declining revenues)

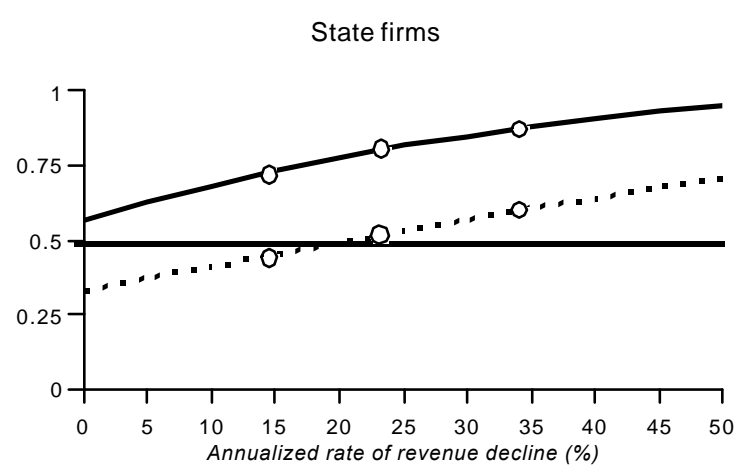

Bank credit

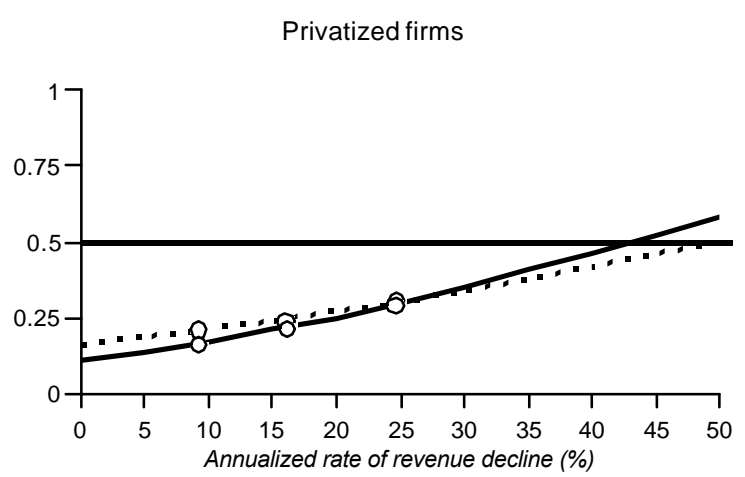

Trade credit

A few other results in Table 1 deserve note. First, the ownership contrast for new private firms in the trade credit equation $(-0.39)$ is significant, implying that those firms show a significantly greater propensity to repay their suppliers than do either state or privatized companies. The most likely explanation of this fact is that all presently or previously state-owned firms have relatively established trade relations with their suppliers, while the nonprivatized private firms are the "new boys on the block," which may make the suppliers less willing to extend credit and the firms themselves more eager to establish their creditworthiness by timely repayments.

Second, the ownership contrast for corporatized firms in the state credit equation $(-0.26)$ is also significant, suggesting that corporatized firms, whose overall payment pattern was not significantly different from that of other state firms, appear significantly less likely to default on their short-term obligations to state creditors than noncorporatized state enterprises. Thus, while previous research shows that corporatization does not significantly affect the revenue or cost performance of a firm (Frydman et al., 1999), it may alter its relationship with state creditors and harden the budget constraints. Whether this is due to a greater resolve of the firm itself or that of its state creditors, the greater expectation of privatization that often accompanies the process of 
corporatization - and thus perhaps the lower likelihood of state bailout - may have played a role.

Finally, some country differences, determining the "environmental" background of creditworthiness, should be noted. Trade creditors seem more likely to collect their payments on time in Hungary than in either the Czech Republic or Poland, perhaps a consequence of the stricter bankruptcy laws in Hungary at the time of our survey. Also, on average, firms in the Czech Republic tend to default less often to state creditors than those in either Hungary and Poland: the Czech government may have been more effective in imposing financial discipline on state and non-state firms alike (this was certainly true about tax payments), but also, according to some reports, Czech banks may have been more willing to capitalize overdue payments. This may have been particularly true in the case of the relation between the firms owned by Czech investment funds and the banks controlling the same funds. ${ }^{10}$

\section{Creditor behavior and the developing credit markets in the postcommunist transition}

We have seen that state-owned firms represent a higher credit risk to short-term creditors than privately-owned firms, both because of their lesser ability to pay and their lower willingness or propensity to repay. In particular, state firms are particularly sluggish in repaying their shortterm obligations to state creditors, while they tend to show grater propensity to satisfy their trade creditors. In this section we examine the extent to which different creditors recognize the differences in the creditworthiness of different types of firms, and in particular, the extent to which their own behavior may be a factor in determining the likelihood of nonrepayment.

As explained previously (in section III above), we assume that direct rationing of shortterm credit (rather than interest rate differentials) is likely to be the main method by which creditors in the transition environment react to perceived excessive credit riskiness of individual borrowers. To the extent that credit allocation in the early years of the transition mirrored the

\footnotetext{
${ }^{10}$ To test this hypothesis, we re-estimated our overall default and bank-credit default equations (columns 1 and 2 in Table 1) separating the firms owned by Czech privatization funds from all other privatized firms. In the overall default equation, the firms owned by the Czech funds were not significantly more likely to default than other privatized companies. But when only the default on bank credit was examined, the firms owned by the Czech privatization funds were significantly more likely to default than other privatized firms, and their payment behavior was in fact not significantly different from that of state firms.
} 
borrowers' creditworthiness, therefore, it was likely to be reflected in the amount of borrowing (degree of leverage) that particular firms might be allowed by their creditors.

But if risk differentials - whether related to ownership, performance, or any other factor affecting credit riskiness - were properly accounted for in determining the allowable degree of leverage, they should not account for any differences in the levels of overdue credit. In other words, if a variable significant in explaining the variation in the incidence of arrears among certain types of firms were to remain significant in explaining the variation in the levels of their arrears as well, the persistence would imply that creditors did not properly take this variable into account in the first place, when they were assessing the creditworthiness (credit riskiness) of the firms' in question. If being state-owned, for example, is a property that partially explains both the likelihood of a firm's default on bank debt and the level of its overdue bank debts, then we conclude that banks, to begin with, do not properly take state ownership as an indication of an increased probability of default and are "soft" in extending credit to state firms.

To examine the determinants of the size of the arrears a firm is allowed to run up by a given type of creditor, we estimated the average size of a firm's arrears as a function of its revenue performance (separating revenue growth into two variables, one for firms with growing, the other with falling revenues), ownership type, and the country in which the firm was located. Because not all firms had arrears, the number of firms in the sample became too low to obtain consistently significant results if the firms were split into too many categories. Consequently, we combined into one category of "state-owned firms" both the corporatized and the non-corporatized state firms, which were not statistically significantly different from each other. Similarly, we combined the privatized and new (nonprivatized) private firms, the coefficients of which were virtually identical, into one category of "privately-owned firms." 11

We, again, estimated separately the arrears run up on short-term obligations to (1) any

${ }^{11}$ Another methodological point is relevant as well: A direct estimation of the determinants of the levels of overdue payments among firms in arrears would produce biased results because a firm with arrears cannot be treated as randomly selected from the population of all firms in the sample. In estimating, for example, the role that ownership plays in determining the level arrears run up by a firm, the fact that state firms are more likely to run up arrears than privatized firms in the first place might skew the impact of ownership on the level of arrears. To correct this problem, we used Heckman's two step estimation procedure (Heckman, 1979; Greene, 1981). 
creditor, (2) bank creditors, (3) tax authorities, (4) combined state creditors, and (5) trade creditors. The resulting estimates are reported in Table 2. (State-owned firms in the Czech Republic served as a reference group.)

\section{TABLE 2: SIZE OF ARREARS ALLOWED BY DIFFERENT CREDITORS}

(OVER 1991-93 PERIOD)

Creditors to which the firm is in arrears

\begin{tabular}{|c|c|c|c|c|c|}
\hline Variable & $\begin{array}{c}\text { (1) } \\
\text { Any } \\
\text { creditor }\end{array}$ & $\begin{array}{c}(2) \\
\text { Bank } \\
\text { creditors }\end{array}$ & $\begin{array}{c}\text { (3) } \\
\text { Tax } \\
\text { authorities }\end{array}$ & $\begin{array}{c}\text { (4) } \\
\text { State (banks } \\
\text { or tax } \\
\text { authorities) }\end{array}$ & $\begin{array}{c}(5) \\
\text { Trade } \\
\text { creditors }\end{array}$ \\
\hline Constant & $\begin{array}{l}38.19 \\
(58.52)\end{array}$ & $\begin{array}{c}12.08 \\
(20.57)\end{array}$ & $\begin{array}{l}-16.68 \\
(40.91)\end{array}$ & $\begin{array}{c}16.63 \\
(45.46)\end{array}$ & $\begin{array}{c}13.45 \\
(14.19)\end{array}$ \\
\hline $\begin{array}{l}\text { Rate of growth of revenues for } \\
\text { firms with decreasing revenues }{ }^{1}\end{array}$ & $\begin{array}{l}-0.32 \\
(1.13)\end{array}$ & $\begin{array}{l}-0.13 \\
(0.29)\end{array}$ & $\begin{array}{l}-0.18 \\
(0.43)\end{array}$ & $\begin{array}{l}-0.29 \\
(0.66)\end{array}$ & $\begin{array}{l}-0.05 \\
(0.23)\end{array}$ \\
\hline $\begin{array}{l}\text { Rate of growth of revenues for } \\
\text { firms with increasing revenues }{ }^{1}\end{array}$ & $\begin{array}{c}0.13 \\
(0.15)\end{array}$ & $\begin{array}{l}0.004 \\
(0.03)\end{array}$ & $\begin{array}{c}0.07 \\
(0.08)\end{array}$ & $\begin{array}{c}0.01 \\
(0.05)\end{array}$ & $\begin{array}{l}0.15 \\
(0.10)\end{array}$ \\
\hline $\begin{array}{l}\text { Privately-owned (privatized or new } \\
\text { private) firm }{ }^{2}\end{array}$ & $\begin{array}{l}-23.22 \\
(25.38)\end{array}$ & $\begin{array}{c}-14.48^{* *} \\
(7.6)\end{array}$ & $\begin{array}{c}-20.86 * * \\
(11.82)\end{array}$ & $\begin{array}{c}-26.37^{*} \\
(12.18)\end{array}$ & $\begin{array}{l}-5.58 \\
(6.52)\end{array}$ \\
\hline Hungary $^{3}$ & $\begin{array}{c}4.28 \\
(14.27)\end{array}$ & $\begin{array}{l}-10.42 \\
(8.64)\end{array}$ & $\begin{array}{c}10.54 \\
(20.87)\end{array}$ & $\begin{array}{c}-1.98 \\
(17.90)\end{array}$ & $\begin{array}{c}0.68 \\
(5.99)\end{array}$ \\
\hline \multirow[t]{2}{*}{ Poland ${ }^{4}$} & $\begin{array}{c}14.26 \\
(18.17)\end{array}$ & $\begin{array}{l}-13.97 \\
(12.27)\end{array}$ & $\begin{array}{c}10.53 \\
(27.92)\end{array}$ & $\begin{array}{c}-0.25 \\
(21.78)\end{array}$ & $\begin{array}{c}8.12 \\
(4.85)\end{array}$ \\
\hline & $\begin{array}{c}\mathrm{n}=79 \\
\mathrm{~F}=2.71 *\end{array}$ & $\begin{array}{c}\mathrm{n}=72 \\
\mathrm{~F}=1.35\end{array}$ & $\begin{array}{c}\mathrm{n}=53 \\
\mathrm{~F}=0.98\end{array}$ & $\begin{array}{c}\mathrm{n}=75 \\
\mathrm{~F}=1.97 * *\end{array}$ & $\begin{array}{c}\mathrm{n}=53 \\
\mathrm{~F}=1.93 * *\end{array}$ \\
\hline
\end{tabular}

*p \# 0.05; **p \# 0.10; significant coefficients bold-faced. Two step Heckman's estimates of sample selection models

Arrears run by a firm are measured as a percentage of the firm's annual revenues. Rates of revenue growth are annualized over the 1991-93 period for state firms and over the post-privatization period for privatized firms. Table B.2 in Appendix B provides the estimates obtaining when the performance of state firms is evaluated over the 1990-93 period.

${ }^{1}$ Annualized rate of revenue growth; revenue are measured in constant local prices

${ }^{2}$ A dummy variable equal to 1 if the firm is either privatized or new private firm, 0 otherwise

${ }^{3}$ A dummy variable equal to 1 if the firm is in Hungary. 0 otherwise

${ }^{4}$ A dummy variable equal to 1 if the firm is in Poland, 0 otherwise

Recall that two factors - revenue performance for firms with declining revenues, and firm 
ownership - explained the incidence of arrears (i.e. the likelihood of default which measured the creditworthiness of the firm). Of these two factors, the rate of revenue growth ceases to be of significance in explaining the differences in the levels of arrears accumulated by different firms, whether overall or to any particular creditor. Thus, all creditors appear to have fully incorporated the revenue performance component of a firm's creditworthiness in determining the credit line open to the firm. However, the ownership contrasts continue to remain significant in explaining the levels of overdue payments some firms were allowed to amass. In particular, the ownership contrast for private firms in the state credit equation (26.37) is significant while that in the trade credit equation $(-5.58)$ is not: state, but not trade, creditors seem to allow state-owned firms to run up higher arrears than the privately-owned firms.

We may only conjecture about the exact reason for the "softness" of state creditors on state-owned firms. It is unlikely that this effect is due to purely informational problems, such as not being able to assess properly the degree of credit risk that state-owned firms represent. Even if non-trade creditors, with their less closer ties to the borrowing firms, may perhaps have somewhat worse access to information, what we are dealing here looks too much like a systematic slant in favor of state firms to be explained in this way.

A more likely reason is that state creditors intentionally favor state-owned firms, either because of a politicization of credit decisions or because of the "old boy" connections between state lenders and the state-owned firms in financial difficulties. Under this view, the differential treatment of state firms by state creditors follows from a correct assessment of these firms' inability to meet their financial obligations, and the extension of credit is consciously meant as a subsidy to state firms that cannot generate sufficient revenues to survive. Moreover, although this kind of policy might have many adverse consequences and goes against the convictions of most committed reformers in the postcommunist countries, ${ }^{12}$ the subsidies in question may not be entirely irrational. For if it is, indeed, the case that privatization is likely to lead to quick improvement in the state firms' performance (as the research to date indicates), then the state

\footnotetext{
12 The ex post bailout of deficient firms through "soft budget constraints" is often blamed for the persistent inefficiency of state firms (Kornai, 1993; Gomulka, 1995).
} 
firms may be legitimately seen as having some turnaround potential, and letting them die by financial strangulation may not appear to be the right policy to the state lenders with long relations to these firms.

But most likely the subsidy is not a result of any conscious policy on the part of the lenders, but rather of their refusal to follow a credit policy that would explicitly discriminate against state firms. State-owned firms are in part less creditworthy because of their lesser ability to pay. Yet the insignificance of revenue performance as a determinant of the size of arrears for these firms means that state creditors seem to have no difficulty in making the ability to pay (perhaps explicitly measured by sales performance) into one of the lending criteria, even if this adversely affects the state firms' ability to obtain credit.

But the second element of the state firms' lower creditworthiness - their lesser willingness or propensity to pay - may be more difficult to handle. To some extent, of course, this component of the credit risk posed by state firms is probably induced by the creditors themselves: if they are softer toward state firms in their credit policies, the state-owned firms, taking advantage of this softness, will show themselves less creditworthy. But this is very likely a chicken-and-egg problem, and we have argued already that, to some extent at least, the state-firms' lower propensity to repay their short-term obligations is probably due to firm-specific (and not creditor specific) factors, such as the high opportunity cost of repayment for state firms that may face political pressure not to lay off workers or engage in other painful cost-cutting restructuring.

Now, to the extent such firm-specific reasons for the state firms' lower propensity to repay are present, it may be very difficult to find a proxy for their existence, other than the very fact of state ownership. If the creditors want to allocate credit according to the real credit risks represented by the borrowing firms, therefore, it might be necessary to adopt a policy of explicit discrimination on the basis of state ownership. And while trade creditors (many of whom are private entities) may be doing just that in not allowing state-owned firms to run up unduly high arrears, state lenders may find it much more difficult to do so, much as an American government-regulated insurer might find it difficult to take gender into account in its pricing decisions, even if it is known that gender is a good proxy for such things as life expectancy or child-birth-related medical expenses. Faced with this peculiar "cognitive constraint," state lenders in the postcommunist countries may 
be forced to ignore the most reliable lending criteria and attempt to follow a "facially neutral," nondiscriminatory policy, which in fact amounts to granting subsidies to the state-owned firms in their portfolios.

Once such a policy is followed, of course, it has the further effect of softening the budget constraint faced by state-owned firms and contributes further to their lower creditworthiness. This is hardly surprising: although some aspects of creditworthiness may be originally firm-specific and others creditor-specific, it invariably "takes two to tango." On the debtor side, the deficiencies of state ownership make state-owned firms a higher credit risk, both because of their lesser ability to pay and their lower propensity to do so. Moreover, both of these characteristics are intrinsic to state ownership: the former because of the constraints state ownership imposes on a firm's ability to generate revenues, the latter because of the politicization of the firm's repayment decisions. On the creditor side, state ownership produces an equally pronounced and ownershipspecific effect, as state creditors are forced to ignore, and perhaps willing to bear the burden of, the higher credit risks represented by state firms, effectively allowing them to extract a significant "risk rent" from the state. The two sides reinforce each other and make the hard budget constraint policy, so dear to most reformers, to some extent unrealistic.

\section{Long-term debt}

The information in our survey concerning long-term debt is less detailed than that concerning short-term obligations. Still, we were able to estimate the long-term debt counterpart of the probability of default equation reported in Table 1. It would be surprising if the differences among firms with different ownership types observed in connection with the likelihood of default on short-term obligations did not carry over to long-term debts - and they do.

We again identify the risk in extending long-term loans with the likelihood of default and measure it by looking at the incidence of debt rescheduling. ${ }^{13}$ We relate this likelihood to the

\footnotetext{
${ }^{13}$ For state and private firms, we score rescheduling at any time between 1991 and 1993; for privatized firms, we take into account only post-privatization rescheduling. This can bias our results, if privatized firms might have had their debts rescheduled prior to privatization. Our data and other information suggest, however, that this is not likely to have been the case. First, in contradistinction to other countries, privatization in the postcommunist transition was generally not preceded by an infusion of new funds to the firms to be privatized. Second, debt rescheduling in our sample appears
} 
rate of growth of a firm's revenues prior to rescheduling, again using separate variables for firms with negative and positive revenue growth, the firm's ownership type, and the country in which it is located. The resulting estimates are reported in Table 4 below. (State enterprises in the Czech Republic serve as a reference group.)

The results mirror those obtained for short-term credit. First, as before, declining revenues are associated with greater likelihood of debt rescheduling, while growing revenues are not. State firms thus present higher risks to long-term lenders on the basis of their ability to repay alone. Second, once the ability to repay is controlled for, state-owned firms are still more likely to have their debts rescheduled than either privatized or private firms. Since most of the long term debt is likely to have come from state sources, we may safely assume that the state firms' lower propensity to repay is partly due to firm-specific and partly to creditor-specific factors and that both may be related to the politicization of credit and repayment decisions. Indeed, the decision to reschedule is also likely to be politicized, as witnessed by the fact that state firms are more likely to reschedule than either private or privatized firms with the same revenue history.

Finally, the environmental factors determining the likelihood of rescheduling are measured by the coefficients on the country dummies. Note in this connection that Czech firms are significantly less likely to reschedule than either their Polish or Hungarian counterparts, which in turn are not significantly different from each other. Whether these differences are due to more difficult formal rescheduling or easier informal roll-overs in the Czech Republic, we were unable to determine.

to have begun in 1993 only: of the 35 state and corporatized firms which reported rescheduling of their debts between 1990 and 1993, 28 had the first instance of rescheduling in 1993 or 1994 and only 1 reported a 1991 rescheduling. Still, the very possibility of bias warrants some caution in interpreting the results reported in this section. 
TABLE 3: RESCHEDULING OF LONG-TERM DEBTS

OVER 1991-93 PERIOD

\begin{tabular}{|c|c|c|c|c|c|c|c|}
\hline Constant & $\begin{array}{l}\text { Prior negative } \\
\text { revenue } \\
\text { growth rate }^{1}\end{array}$ & $\begin{array}{l}\text { Prior positive } \\
\text { revenue } \\
\text { growth rate }\end{array}$ & $\begin{array}{l}\text { Corporatized } \\
\text { firm }^{3}\end{array}$ & $\begin{array}{l}\text { Privatized } \\
\text { firm }^{4}\end{array}$ & Private firm ${ }^{5}$ & Hungary $^{6}$ & Poland $^{7}$ \\
\hline $\begin{array}{l}-0.40^{*} \\
(0.38)\end{array}$ & $\begin{array}{c}-0.008 * \\
(0.002)\end{array}$ & $\begin{array}{c}0.000 \\
(0.002)\end{array}$ & $\begin{array}{l}-0.05 \\
(0.10)\end{array}$ & $\begin{array}{l}-0.17 * * \\
(0.09)\end{array}$ & $\begin{array}{l}-0.23 * \\
(0.09)\end{array}$ & $\begin{array}{l}0.25 * \\
(0.08)\end{array}$ & $\begin{array}{l}0.27 * \\
(0.08)\end{array}$ \\
\hline
\end{tabular}

*p \#0.05 **p \#0.10; significant coefficients bold-faced. Maximum likelihood estimates of a binomial probit model

Dependent variable equal to 1 if a firm had its long term debt rescheduled, 0 otherwise. For state and private firms, the value is set to 1 if the firm rescheduled its debt between 1991 and 1993. For privatized firms, the value is set to 1 if the firm rescheduled its debt in the post-privatization period. Table B.3 in Appendix B provides the estimates pertaining to the $1990-93$ period.

${ }^{1}$ Annualized rate of pre-rescheduling revenue growth for firms for which the rate is negative.

${ }^{2}$ Annualized rate of pre-rescheduling revenue growth for firms for which the rate is positive.

${ }^{3}$ A dummy variable equal to 1 if the firm is a corporatized enterprise, 0 otherwise

${ }^{4}$ A dummy variable equal to 1 if the firm is a privatized enterprise, 0 otherwise

${ }^{5}$ A dummy variable equal to 1 if the firm is a private enterprise never previously owned by the state, 0 otherwise

${ }^{6}$ A dummy variable equal to 1 if the firm is in Hungary, 0 otherwise

${ }^{7}$ A dummy variable equal to 1 if the firm is in Poland, 0 otherwise

\section{Conclusions}

The choice of policies underlying various prescriptions for emerging economies in times of economic crises depends on the extent to which financial discipline can improve firm performance. This paper shows, using the example of the postcommunist economies, that the there are clear limits to what financial discipline can accomplish in the absence of firm-level restructuring.

Previous research has established that the introduction of financial discipline on state firms in the postcommunist transition environment is quite effective in forcing them to restructure the costs of their operation, even if a degree of politicization of such things as employment reductions continues to hamper their performance. Hard budget constraints have been largely ineffective, however, in improving the revenue performance of state-owned firms, as the markets for their goods continue to shrink and their restructuring efforts do not produce the desired results. 
But the ability to generate revenues, more than any other factor, determines a firm's ability to repay its obligations in the economic upheavals following the fall of the communism. As a result, unless accompanied by privatization, the policy of hard budget constraints can be only partially successful. As state firms lose their markets, they encounter increasing difficulties with servicing their debt obligations, and they tend to put pressure on their creditors to allow them some slack in repayment discipline. While the mostly private trade creditors seem to resist these pressures and respond with penalizing state firms for the lesser willingness or propensity to repay, state creditors are more receptive. Whether as a conscious policy or because of their reluctance to engage in explicit discrimination against state firms that a market-based credit allocation would require, the state creditors cannot help but respond to the state firms' desperate situation. Moreover, given the fact that many state firms could be turned around by privatization, the state creditors' might find it particularly difficult to let them perish by cutting off the supply of credit. But extending credit on softer terms to state firms than to their privatized and new private counterparts is also very dangerous and breeds a cycle of deteriorating financial discipline. Our conclusion, therefore, is not that the hard budget constraints of the postcommunist reform policies should be relaxed. It is rather that these policies are not realistic, unless accompanied by speedy privatization. In the broader context of the emerging economies, this means that firmlevel restructuring may be a necessary complement of financial discipline if the transition to a well-functioning market economy is to be successful. 


\section{REFERENCES}

Balcerowicz, Leszek, Cheryl W. Gray, and I. Hashi, 1997. Exit Processes in Transition Economies: Downsizing, Workouts, and Liquidation. Central European University Press, Budapest.

Coffee, John C.,1996. Institutional Investors in Transitional Economies, in Roman Frydman, Cheryl W. Gray, and Andrzej Rapaczynski, eds., Corporate Governance in Central Europe and Russia. Volume 1: Banks, Funds, and Foreign Investors. Central European University Press, Budapest.

Frydman, R., C.W. Gray, M. Hessel, and A. Rapaczynski, 1999. When Does Privatization Work? The Impact of Private Ownership on Corporate Performance in the Transition Economies. Quarterly Journal of Economics (forthcoming ).

Frydman, Roman, Marek Hessel, and Andrzej Rapaczynski, 1997. Why Ownership Matters? Politicization and Entrepreneurship in the Restructuring of Enterprises in Central Europe. C.V. Starr Center for Applied Economics, New York University.

Gomulka, Stanislaw, 1985. Kornai's Soft Budget Constraint and the Shortage Phenomenon: A Criticism and a Restatement. Economics of Planning 19 (1): 1-11.

Greene, William, 1981. Sample Selection Bias as a Specification Error: Comment, Econometrica Heckman, J., 1979. Sample Selection Bias as a Specification Error, Econometrica

Kornai, Janos, 1993. The Evolution of Financial Discipline under the Postsocialist System, Kyklos $46(3): 315-336$

Kornai, Janos, 1990. The Road to a Free Economy. Shifting from a Socialist System: The Example of Hungary. W.W. Norton, New York.

Pinto, B., Marek Belka, and S. Krajewski, 1993. Transforming State Enterprises in Poland: Evidence on Adjustment By Manufacturing Firms, Brookings Papers on Economic Activity, 1: 213-269.

Schaffer, Mark E., 1998. Do Firms in Transition Economies Have Soft Budget Constraints? A Reconsideration of Concepts and Evidence. Journal of Comparative Economics 26 (1).

Stiglitz, George and A.Weiss, 1981. Credit Rationing in Markets with Imperfect Information. American Economic Review 71: 393-410 


\section{APPENDIX A: SAMPLE DESCRIPTION}

The study is based on a survey of 506 mid-size firms conducted in the fall of 1994 in the Czech Republic, Hungary, and Poland. The sample was drawn from firms employing between 100 and 1,500 persons. The procedure used was to draw randomly from the list of firms provided by the Central Statistical Office in each country, but when a maximum of firms with a certain type of owners was reached, further firms with the same ownership type were not included in the survey. (No such adjustments were necessary in Hungary.) Separate interviews (using different close-ended questionnaires) were conducted in each firm with the chief executive officer, the chief financial officer, and the chief production officer, each of whom was asked about matters in his particular area of expertise. An additional questionnaire, requesting time series data on revenues, labor and material costs, employment, and taxes, was filled out at each firm by the accounting department.

The present study is based on a subsample of the original 506 firms. First, we excluded from the subsample 86 firms the ownership structure of which was unclear. Second, to allow for the analysis of post-privatization performance, we further limited the subsample of privatized firms ${ }^{14}$ to those privatized in 1990, 1991, and 1992 (thus excluding 87 privatized in 1993 or 1994, for which no post-privatization data was available). Beyond these exclusions, some firms did not provide complete data on all aspects of their performance. ${ }^{15}$ The number of firms actually used in the analysis thus varies with the particular aspect of performance under examination, but the total number of firms in the largest subsample used here was 216 firms (see Table A.2).

Both state-owned and privatized firms in the sample were generally larger than the new private firms. The initial (1990 for state firms, year of privatization for privatized firms) mean annual sales of state-owned and privatized firms were US\$16.4 million and US\$13.9 million, respectively, with the corresponding mean initial employment levels of 743 and 661 full-time employees, while the respective initial (1990 or year of establishment, if later) values for the new private firms were US\$ 5.05 and 164 employees (see Table A.1). These firms operated both in consumer goods (food and beverages, clothing, and furniture) and in industrial goods sectors (non-ferrous minerals, chemicals, textiles and leather), with roughly $56 \%$ of privatized firms, $64 \%$ of state firms, $45 \%$ of corporatized firms, and $71 \%$ of new private firms in consumer goods sectors. (See Table A.3.)

\footnotetext{
${ }^{14}$ By a privatized firm we mean an enterprise (partially or totally) privatized through a privatization of a predecessor state-owned company (or its part) in which the combined holdings of private parties give them a blocking power. We consider private parties to have blocking power if they control the percentage of votes formally sufficient to block major decisions at the general shareholder meeting. Note that this means that in some (15\%) of the firms classified as privatized in this paper, the state remains a majority shareholder. But the high concentration of holdings in our sample makes the difference between blocking and majority power of little significance.

${ }^{15}$ We have no reason to believe that the incompleteness of data for certain firms introduces any systematic bias "in favor" or "against" any group of firms. The most common reason for incompleteness was lack availability or an obvious misunderstanding of the meaning of certain questions, such as those concerning the initial period for which data were to have been provided.
} 
All privatized firms in the sample had highly concentrated ownership: except for privatization funds, the average holdings of private parties in the position of the largest owner were majority holdings. The sole exception - privatization funds - was due to legal limitations. All of these institutions in our sample were in the Czech Republic, and their individual holdings in any one firm were legally capped at 20 percent. Even then, the combined holdings of different funds (which often cooperated with each other) in a single firm typically added up to a majority. The most frequent among those owners in our sample are foreign investors (the largest shareholders in nearly $30 \%$ of privatized firms), followed by managerial or non-managerial employees (over $20 \%$ of privatized firms.) (See Table A.4)

\section{A.1 Distributions OF INITIAL AND LAST-PERIOD REVENUES AND EMPLOYMENT}

\begin{tabular}{|l|c|c|c||c|c|c|}
\hline \multirow{2}{*}{ Firm type } & \multicolumn{3}{|c||}{$\begin{array}{c}\text { Initial / ending revenue } \\
\text { (US\$ mil, constant prices) }\end{array}$} & \multicolumn{3}{|c|}{$\begin{array}{c}\text { Initial / ending } \\
\text { employment }\end{array}$} \\
\cline { 2 - 6 } & Firms & Mean & Median & Firms & Mean & Median \\
\hline
\end{tabular}

ALL COUNTRIES

\begin{tabular}{|l|r|r|r|r|r|r|}
\hline State & 30 & $7.80 / 5.32$ & $5.39 / 4.19$ & 30 & $663 / 424$ & $532 / 349$ \\
Corporatized & 38 & $23.13 / 15.89$ & $12.20 / 8.47$ & 37 & $807 / 639$ & $536 / 445$ \\
Privatized & 93 & $13.90 / 13.76$ & $5.45 / 5.98$ & 79 & $661 / 596$ & $376 / 335$ \\
Private & 55 & $5.05 / 6.98$ & $1.16 / 6.98$ & 55 & $164 / 192$ & $88 / 140$ \\
\hline
\end{tabular}

\section{CZECH REPUBLIC}

\begin{tabular}{|l|r|r|r|r|r|r|}
\hline State & 11 & $12.57 / 7.44$ & $10.86 / 5.44$ & 10 & $859 / 454$ & $565 / 372$ \\
Corporatized & 5 & $37.36 / 26.74$ & $39.74 / 19.46$ & 6 & $1832 / 1249$ & $2168 / 1349$ \\
Privatized & 43 & $13.90 / 16.05$ & $5.35 / 8.40$ & 33 & $800 / 757$ & $376 / 335$ \\
Private & 11 & $2.51 / 4.83$ & $1.48 / 2.41$ & 7 & $123 / 164$ & $43 / 123$ \\
\hline
\end{tabular}

\section{HUNGARY}

\begin{tabular}{|l|c|c|c|c|c|c|}
\hline Corporatized & 25 & $21.27 / 13.30$ & $8.09 / 6.14$ & 24 & $505 / 416$ & $333 / 290$ \\
Privatized & 44 & $13.13 / 10.73$ & $5.77 / 5.13$ & 40 & $480 / 423$ & $296 / 260$ \\
Private & 21 & $2.32 / 3.01$ & $0.57 / 1.43$ & 22 & $138 / 172$ & $83 / 119$ \\
\hline
\end{tabular}

\section{POLAND}

\begin{tabular}{|l|r|r|r|r|r|l|}
\hline State & 19 & $5.04 / 4.10$ & $5.02 / 3.57$ & 20 & $565 / 410$ & $471 / 324$ \\
Corporatized & 8 & $19.81 / 17.18$ & $14.60 / 12.86$ & 7 & $963 / 881$ & $969 / 902$ \\
Privatized & 6 & $19.45 / 19.52$ & $21.64 / 17.76$ & 6 & $1107 / 861$ & $786 / 752$ \\
Private & 23 & $8.77 / 11.63$ & $4.44 / 7.73$ & 26 & $199 / 217$ & $116 / 151$ \\
\hline
\end{tabular}


A.2 COUNTRY DISTRIBUTION OF SAMPLE FIRMS

\begin{tabular}{|c|c|c|c|c|c|}
\hline & Firm type & Czech R & Hungary & Poland* & All \\
\hline $\begin{array}{l}\text { State firms** } \\
\text { of which } \\
\text { Privatized firms } \\
\qquad \text { of which } \\
\text { Private firms }\end{array}$ & $\begin{array}{l}\text { corporatized } \\
\text { privatized in } 1990^{* * * *} \\
\text { privatized in } 1991 \\
\text { privatized in } 1992\end{array}$ & $\begin{array}{rr}16 & \\
43 & \\
- & \\
11 & 5 \\
& 38\end{array}$ & $\begin{array}{lr}25 & \\
44 & \\
& \\
& 12 \\
& \\
21 & 19\end{array}$ & $\begin{array}{cr}27 & \\
& 8 \\
6 & \\
& 2 \\
& 4 \\
& \\
2 & \\
23 & \end{array}$ & $\begin{array}{c}68 \\
93 \\
93 \\
\\
\\
24 \\
22 \\
57 \\
55\end{array}$ \\
\hline All & & 70 & 90 & 56 & 216 \\
\hline
\end{tabular}

* Because many Polish firms were privatized late (after 1992) and many were privatized through leasing (and are thus excluded from the subsample used in this paper, most of the privatized firms in the subsample are in Hungary or the Czech Republic.

** Extensive tests revealed no significant performance differences between state and corporatized firms in our sample.

*** In the Czech Republic, the year of privatization refers to the year in which the new owners assumed control rather than the year during which the shares were formally distributed

\section{A.3 SeCtORAL DISTRIBUTION OF SAMPLE FIRMS ( TWO-DIGIT SIC CODES)}

\begin{tabular}{|c|c|c|c|c|}
\hline \multirow{2}{*}{ Industrial sector } & \multicolumn{4}{|c|}{ Percentage (number) of firms } \\
\hline & state & corporatized & privatized & private \\
\hline Food\&beverages & $20 \%(6)$ & $24 \% \quad(9)$ & $29 \% \quad(27)$ & $22 \% \quad(12)$ \\
\hline Clothing & $17 \%$ & $8 \% \quad(3)$ & $18 \% \quad(17)$ & $40 \% \quad(22)$ \\
\hline Furniture & $27 \%(8)$ & $13 \% \quad(5)$ & $9 \% \quad(8)$ & $9 \% \quad(5)$ \\
\hline Textile & - & $16 \% \quad(6)$ & $9 \% \quad(8)$ & $5 \%$ \\
\hline Leather & - & $13 \% \quad(5)$ & $7 \% \quad(7)$ & $11 \%$ \\
\hline Chemicals & $13 \%(4)$ & $16 \% \quad(6)$ & $9 \% \quad(8)$ & $4 \% \quad(2)$ \\
\hline Non-ferrous & $13 \%(4)$ & $8 \% \quad(3)$ & $18 \%(17)$ & $9 \% \quad(5)$ \\
\hline minerals & $10 \%(3)$ & $2 \% \quad(1)$ & $1 \% \quad(1)$ & - \\
\hline Other & & & & \\
\hline
\end{tabular}




\section{A.4 OWNERSHIP STRUCTURE OF PRIVATIZED FIRMS}

\begin{tabular}{|c|c|c|}
\hline Shareholder & $\begin{array}{l}\text { Number of firms } \\
\text { in which } \\
\text { the shareholder } \\
\text { is the largest owner }\end{array}$ & $\begin{array}{l}\text { Mean holdings } \\
\text { when } \\
\text { the shareholder is } \\
\text { the largest owner }\end{array}$ \\
\hline $\begin{array}{l}\text { Foreign company } \\
\text { Czech Republic } \\
\text { Hungary } \\
\text { Poland } \\
\text { Privatization fund } \\
\text { Czech Republic } \\
\text { Domestic nonfinancial company } \\
\text { Czech Republic } \\
\text { Hungary } \\
\text { Poland } \\
\text { Czech Republic } \\
\text { Hungary } \\
\text { Poland } \\
\text { Domestic individual } \\
\text { Czech Republic } \\
\text { Hungary } \\
\text { Poland } \\
\text { State or state-owned company } \\
\text { Czech Republic } \\
\text { Hungary } \\
\text { Poland } \\
\text { Managerial employees } \\
\text { Hungary }\end{array}$ & 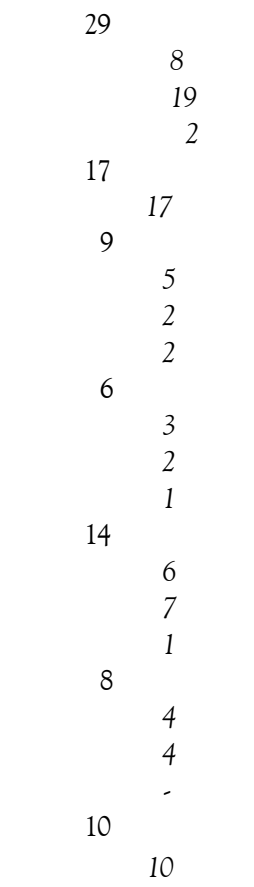 & $\begin{array}{ll}78 \% & \\
& 72 \% \\
& 84 \% \\
& 40 \% \\
20 \% & \\
& 20 \% \\
71 \% & \\
& 73 \% \\
& 77 \% \\
& 60 \% \\
61 \% & \\
& 60 \% \\
& 52 \% \\
& 80 \% \\
44 \% & \\
& 36 \% \\
& 49 \% \\
& 60 \% \\
78 \% & 87 \% \\
& 69 \% \\
74 \% & - \\
& 74 \% \\
\end{array}$ \\
\hline
\end{tabular}




\section{APPENDIX B: REGRESSION ESTIMATES WITH THE REVENUE PERFORMANCE OF STATE FIRMS EVALUATED OVER 1990-93.}

In order to smooth year-to-year variations, the revenue performance of the firms in the sample is usually annualized over a number of years according to the following formula: if $R_{t}$ denotes a firm's performance level in year $t$, the annualized rate of revenue growth, $A R R G$, is an imputed rate which satisfies $P_{T} / P_{t}=(1+A R R G)^{(T-t)}$ over the appropriate time interval $(T-t)$, $T>t$

In the regressions reported in this paper the revenue performance of privatized firms is generally measured between the time of privatization and 1993 (which is the last year for which we have annual data in our sample). Since different firms were privatized at different times (1990, 1991, 1992), attempting to keep the time interval the same for state and privatized firms would necessitate three different sets of comparisons, each of which would compare a relatively small number of firms privatized in a given year to the same set of state firms. We therefore decided, for most purposes, to group all privatized firms together.

This raises the question of the period over which the performance of state firms should be measured. Any particular choice could, in principle, bias the results. For example, if 1990 was a bad recessionary year for all firms and if there were only a handful of firms privatized in 1990, a comparison of the growth rates of state firms annualized over the 1990-1993 period with the growth rates of the privatized firms annualized over the 1991-1993 or 1992-1993 periods could make the performance of state firms look artificially weak. To avoid this problem, we estimated the performance of state firms over two different periods: 1990-93 and 1991-93. This produced two sets of estimates for each equation, one of which (using the 1991-1993 period, which generally happens to be the most "favorable" for state firms) is reported in the text of this paper; the estimates obtained using 1990-93 period to measure the performance of state firms are presented in this Appendix. Note, however, that with a few exceptions noted in the text, the results are essentially invariant with respect to the time period used: the estimates retain their signs and significance across all three sets, indicating that different macroeconomic conditions in different years do not affect our results. 


\title{
TABle B.1： Probability of Default on Obligations TO DIFFERENT TYPES OF CREDITORS
}

\author{
(REVENUE PERFORMANCE OF STATE FIRMS EVALUATED OVER 1990-93 PERIOD)
}

Creditors to whom the debt is owed

\begin{tabular}{|c|c|c|c|c|c|}
\hline Variable & $\begin{array}{c}(1) \\
\text { Any creditors }\end{array}$ & $\begin{array}{c}(2) \\
\text { Bank } \\
\text { creditors }\end{array}$ & $\begin{array}{c}(3) \\
\text { Tax authorities }\end{array}$ & $\begin{array}{c}\text { (4) } \\
\text { State (banks or } \\
\text { tax authorities) }\end{array}$ & $\begin{array}{c}(5) \\
\text { Trade } \\
\text { creditors }\end{array}$ \\
\hline Constant & $\begin{array}{l}-0.04 \\
(0.15)\end{array}$ & $\begin{array}{l}-0.16 \\
(0.12)\end{array}$ & $\begin{array}{r}-0.29^{*} \\
(0.09)\end{array}$ & $\begin{array}{l}-0.23 * * \\
(0.13)\end{array}$ & $\begin{array}{l}-0.12 \\
(0.10)\end{array}$ \\
\hline $\begin{array}{l}\text { Rate of growth of revenues for } \\
\text { firms with decreasing revenues }{ }^{1}\end{array}$ & $\begin{array}{l}-0.013 * \\
(0.004)\end{array}$ & $\begin{array}{c}-0.011 * \\
(0.003)\end{array}$ & $\begin{array}{c}-0.008 * \\
(0.002)\end{array}$ & $\begin{array}{c}-0.013 * \\
(0.003)\end{array}$ & $\begin{array}{c}-0.006^{*} \\
(0.002)\end{array}$ \\
\hline $\begin{array}{l}\text { Rate of growth of revenues for } \\
\text { firms with increasing revenues }\end{array}$ & $\begin{array}{c}0.000 \\
(0.001)\end{array}$ & $\begin{array}{l}0.000 \\
(0.000)\end{array}$ & $\begin{array}{l}0.000 \\
(0.000)\end{array}$ & $\begin{array}{l}-0.000 \\
(0.000)\end{array}$ & $\begin{array}{l}-0.000 \\
(0.000)\end{array}$ \\
\hline Corporatized firm ${ }^{2}$ & $\begin{array}{l}-0.14 \\
(0.16)\end{array}$ & $\begin{array}{l}-0.37^{*} \\
(0.14)\end{array}$ & $\begin{array}{r}-0.32 * \\
(0.11)\end{array}$ & $\begin{array}{l}-0.27 * * \\
(0.14)\end{array}$ & $\begin{array}{l}0.015 \\
(0.11)\end{array}$ \\
\hline Privatized firm ${ }^{3}$ & $\begin{array}{l}-0.35^{*} \\
(0.15)\end{array}$ & $\begin{array}{r}-0.46^{*} \\
(0.13)\end{array}$ & $\begin{array}{c}-0.37 * \\
(0.10)\end{array}$ & $\begin{array}{r}-0.37^{*} \\
(0.13)\end{array}$ & $\begin{array}{l}-0.09 \\
(0.10)\end{array}$ \\
\hline Private (non-privatized) firm $^{4}$ & $\begin{array}{c}-0.38^{*} \\
(0.16)\end{array}$ & $\begin{array}{c}-0.43 * \\
(0.14)\end{array}$ & $\begin{array}{c}-0.32 * \\
(0.10)\end{array}$ & $\begin{array}{c}-0.31 * \\
(0.14)\end{array}$ & $\begin{array}{c}-0.38^{*} \\
(0.11)\end{array}$ \\
\hline Hungary $^{5}$ & $\begin{array}{c}0.13 \\
(0.10)\end{array}$ & $\begin{array}{l}0.27 * \\
(0.10)\end{array}$ & $\begin{array}{l}0.35^{*} \\
(0.08)\end{array}$ & $\begin{array}{l}0.31 * \\
(0.09)\end{array}$ & $\begin{array}{c}-0.14^{* *} \\
(0.08)\end{array}$ \\
\hline \multirow[t]{2}{*}{ Poland $^{6}$} & $\begin{array}{c}0.14 \\
(0.12)\end{array}$ & $\begin{array}{l}0.34^{*} \\
(0.11)\end{array}$ & $\begin{array}{l}0.38 * \\
(0.09)\end{array}$ & $\begin{array}{l}0.29 * \\
(0.11)\end{array}$ & $\begin{array}{l}-0.02 \\
(0.09)\end{array}$ \\
\hline & $\begin{array}{c}\mathrm{n}=175 \\
\mathrm{P}^{2}=43.36\end{array}$ & $\begin{array}{c}\mathrm{n}=209 \\
\mathrm{P}^{2}=67.59\end{array}$ & $\begin{array}{c}\mathrm{n}=216 \\
\mathrm{P}^{2}=77.83\end{array}$ & $\begin{array}{c}\mathrm{n}=201 \\
\mathrm{P}^{2}=53.14\end{array}$ & $\begin{array}{c}\mathrm{n}=204 \\
\mathrm{P}^{2}=38.48\end{array}$ \\
\hline
\end{tabular}

*p \#0.05 **p \#0.10; significant coefficients bold-faced. Maximum likelihood estimates of binomial probit models

${ }^{1}$ The rates of revenue growth are annualized over the 1990-93 period for state firms and over the post-privatization period for privatized firms. Revenues are measured in constant local prices.

${ }^{2}$ A dummy variable equal to 1 if the firm is corporatized, zero otherwise.

${ }^{3}$ A dummy variable equal to 1 if the firm is privatized, zero otherwise.

${ }^{4}$ A dummy variable equal to 1 if the firm is a newly-founded by private parties, zero otherwise.

${ }^{5}$ A dummy variable equal to 1 if the firm is in Hungary, zero otherwise.

${ }^{6}$ A dummy variable equal to 1 if the firm is in Poland, zero otherwise. 


\section{TABLE B.2: SIZE OF ARREARS ALLOWED BY DIFFERENT CREDITORS}

(REVENUE PERFORMANCE OF STATE FIRMS EVALUATED OVER 1990-93 PERIOD)

(1)

Any creditor
(2)

Bank creditors
(3)

Tax authorities
(4)

State (banks or Trade creditors tax authorities)

\begin{tabular}{|c|c|c|c|c|c|}
\hline Constant & $\begin{array}{r}-4.42 \\
(62.94)\end{array}$ & $\begin{array}{c}6.52 \\
(22.19)\end{array}$ & $\begin{array}{l}-26.27 \\
(42.02)\end{array}$ & $\begin{array}{c}-1.15 \\
(47.27)\end{array}$ & $\begin{array}{l}17.03 \\
(14.86)\end{array}$ \\
\hline $\begin{array}{l}\text { Rate of growth of revenues for } \\
\text { firms with decreasing revenues }\end{array}$ & $\begin{array}{l}-0.30 \\
(1.19)\end{array}$ & $\begin{array}{l}-0.12 \\
(0.32)\end{array}$ & $\begin{array}{l}-0.23 \\
(0.46)\end{array}$ & $\begin{array}{l}-0.35 \\
(0.69)\end{array}$ & $\begin{array}{l}0.02 \\
(0.23)\end{array}$ \\
\hline $\begin{array}{l}\text { Rate of growth of revenues for } \\
\text { firms with increasing revenues }\end{array}$ & $\begin{array}{l}-0.07 \\
(0.14)\end{array}$ & $\begin{array}{r}-0.004 \\
(0.03)\end{array}$ & $\begin{array}{l}-0.07 \\
(0.08)\end{array}$ & $\begin{array}{l}-0.01 \\
(0.05)\end{array}$ & $\begin{array}{l}0.04 \\
(0.09)\end{array}$ \\
\hline $\begin{array}{l}\text { Privately-owned (privatized or } \\
\text { new private) firm }\end{array}$ & $\begin{array}{l}-37.86 \\
(25.78)\end{array}$ & $\begin{array}{c}-15.25 * \\
(7.48)\end{array}$ & $\begin{array}{l}-21.49 * * \\
(11.45)\end{array}$ & $\begin{array}{l}-28.42 * \\
(11.94)\end{array}$ & $\begin{array}{l}-2.72 \\
(6.91)\end{array}$ \\
\hline Hungary ${ }^{3}$ & $\begin{array}{c}2.63 \\
(15.03)\end{array}$ & $\begin{array}{r}-10.74 \\
(8.86)\end{array}$ & $\begin{array}{c}9.17 \\
(20.77)\end{array}$ & $\begin{array}{l}-2.24 \\
(18.22)\end{array}$ & $\begin{array}{l}-1.10 \\
(6.37)\end{array}$ \\
\hline \multirow[t]{2}{*}{ Poland ${ }^{4}$} & $\begin{array}{c}13.93 \\
(19.22)\end{array}$ & $\begin{array}{l}-13.73 \\
(12.56)\end{array}$ & $\begin{array}{l}10.13 \\
(27.80)\end{array}$ & $\begin{array}{c}0.43 \\
(22.10)\end{array}$ & $\begin{array}{l}7.25 \\
(5.26)\end{array}$ \\
\hline & $\begin{array}{c}\mathrm{n}=79 \\
\mathrm{~F}=2.92 *\end{array}$ & $\begin{array}{c}\mathrm{n}=72 \\
\mathrm{~F}=1.40\end{array}$ & $\begin{array}{c}\mathrm{n}=53 \\
\mathrm{~F}=1.10\end{array}$ & $\begin{array}{c}\mathrm{n}=75 \\
\mathrm{~F}=2.16^{* *}\end{array}$ & $\begin{array}{c}\mathrm{n}=53 \\
\mathrm{~F}=1.30\end{array}$ \\
\hline
\end{tabular}

*p \#0.05; **p \#0.10; significant coefficients bold-faced. Two step Heckman's estimates of sample selection models

Arrears run by a firm are measured as a percentage of the firm's annual revenues

${ }^{1}$ Annualized rate of revenue growth; revenue are measured in constant local prices

${ }^{2}$ A dummy variable equal to 1 if the firm is either privatized or new private firm, 0 otherwise

${ }^{3}$ A dummy variable equal to 1 if the firm is in Hungary. 0 otherwise

${ }^{4}$ A dummy variable equal to 1 if the firm is in Poland, 0 otherwise 
TABLE B.3: RESCHEDULING OF LONG-TERM DEBTS

OVER 1990-93 PERIOD

\begin{tabular}{cccccccc} 
Constant & $\begin{array}{c}\text { Prior } \\
\text { negative } \\
\text { revenue } \\
\text { growth rate }\end{array}$ & $\begin{array}{c}\text { Prior } \\
\text { positive } \\
\text { revenue } \\
\text { growth rate }\end{array}$ & $\begin{array}{c}\text { Corporatized } \\
\text { firm }^{3}\end{array}$ & $\begin{array}{c}\text { Privatized } \\
\text { firm }^{4}\end{array}$ & Private firm $^{5}$ & Hungary $^{6}$ & Poland $^{7}$ \\
\hline$-0.39^{*}$ & $\begin{array}{c}-0.007^{*} \\
(0.002)\end{array}$ & $\begin{array}{c}-0.000 \\
(0.000)\end{array}$ & $\begin{array}{c}0.06 \\
(0.10)\end{array}$ & $\begin{array}{c}-0.17^{* *} \\
(0.10)\end{array}$ & $\begin{array}{c}-0.23^{*} \\
(0.10)\end{array}$ & $\begin{array}{c}0.25^{*} \\
(0.08)\end{array}$ & $\begin{array}{c}0.27 * \\
(0.08)\end{array}$ \\
\hline
\end{tabular}

*p \#0.05**p \#0.10. Maximum likelihood estimates of a binomial probit model

Dependent variable equal to 1 if a firm had its long term debt rescheduled, 0 otherwise. For state and private firms, the value is set to 1 if the firm rescheduled its debt between 1990 and 1993 . For privatized firms, the value is set to 1 if the firm rescheduled its debt in the post-privatization period.

${ }^{1}$ Annualized rate of pre-rescheduling revenue growth for firms for which the rate is negative.

${ }^{2}$ Annualized rate of pre-rescheduling revenue growth for firms for which the rate is positive.

${ }^{3}$ A dummy variable equal to 1 if the firm is a corporatized enterprise, 0 otherwise

${ }^{4}$ A dummy variable equal to 1 if the firm is a privatized enterprise, 0 otherwise

${ }^{5}$ A dummy variable equal to 1 if the firm is a private enterprise never previously owned by the state, 0 otherwise

${ }^{6}$ A dummy variable equal to 1 if the firm is in Hungary, 0 otherwise

${ }^{7}$ A dummy variable equal to 1 if the firm is in Poland, 0 otherwise 